\title{
Board Characteristics, Performance and Risk Taking Behaviour in Tunisian Banks
}

\author{
Houssem Rachdi, Ph.D. \\ Faculty of Economic Sciences and Management of Tunis \\ University of Tunis El Manar, Tunisia \\ Tel: 216-98-650-660Ｅ-mail: rachdih@uvic.ca \\ Ines Ghazouani Ben Ameur, Ph.D. \\ TIME Université, Tunisia \\ Tel: 216-20-989-698Ｅ-mail: inesghazouani@hotmail.com
}

Received: December 17, $2010 \quad$ Accepted: May 5, $2011 \quad$ doi:10.5539/ijbm.v6n6p88

\begin{abstract}
The existing literature provides conflicting views of the relationship among board characteristics; performance (Return on Assets and Return on Equity) and bank risk taking (Z-score). The relation between characteristics of corporate boards, firm performance and risk taking continues to be a fundamental issue in the corporate governance literature. Findings of this literature are often inconclusive. The main contribution of this study is an analysis of how board characteristics affect performance and incentives to take risk in banking industry. We explore this relationship by using both generalized least square (GLS) random effect (RE) and generalized method of moments (GMM) system approaches. The empirical analysis based on a sample of 11 large Tunisian commercial banks during 1997-2006, reports the following robust results: a small bank board is associated with more performance and with more bank risk-taking, the presence of independent directors within the board of directors affects negatively the performance, but has no significant effect on the risk-taking, a lower CEO ownership is associated with lower performance in Tunisian banks, banks with high charter value are associated with lower ROA and ROE and more bank risk and the small size banks institutions appear to assume lower risks. Our results support the idea, commonly accepted, that bank board structure is a determinant factor for bank performance and bank risk taking.
\end{abstract}

Keywords: Board characteristics, Performance, Bank risk, GLS RE and GMM system

\section{Introduction}

After the collapse of Enron in 2001, the literature of banking governance has exploded. Using the database EconLit from American Economic Association, Morey et al. (2009) found that approximately 53\% of academic papers, about corporate governance, were published since the Enron crisis in 2001, while only $47 \%$ of the listings were published between 1969 through 2001. The theory of corporate governance treats the whole of the internal and external mechanisms in solving agency conflicts and reducing costs which result from it. Among internal governance mechanism, we find the board of directors. According to Lefort and Urzúa (2008), board of directors is a central institution in the internal governance of a firm. Referring to Smith (1776), board of directors is defined as: "The directors of companies, however, being the managers rather of other people's money than of their own, it cannot well be expected, that they should watch over it with the same anxious vigilance (as owners)...negligence and profusion, therefore, must always prevail, more of less, in the management of the affairs of such accompany". Jenson (1993) affirms that the characteristics of board of directors (size, composition, ownership structure) are as many instruments which reflect the effectiveness of the board in his activity of the control of managers. Mixed findings, both theoretical and empirical, have been provided on this issue by the academic research.

Adams and Mehran (2003) and Caprio et al. (2007) underline the fact that only few scientific papers treat banking governance. The special nature of banking business requires the implementation of more specific and complex 
mechanisms for banking governance. Referring to Pathan and Skully (2010), the recent global financial and banking crises also highlights the importance of improving understanding of bank governance. Now it is unanimously recognized that banking industry must be structured by specific and rigorous rules, aiming at limiting the risks which it can incur. Banking governance is conceived primarily to establish an effective banking structure with full potentiality in the financing of the economy. Consequently, bad banking governance is likely to affect negatively all the banking system and to generate harmful effects on the economy.

Because banks are reduced to the theory of the firm, mechanisms of corporate governance can be transposed to banks. Pathan et al. (2008) confirm that much of empirical models results corporate governance, performance and risk behaviour in corporate firms are also applicable to banks. Banking governance can be either through internal mechanism (board of directors) or external mechanism (banking regulation and supervision, ownership structure...). In the report "Enhancing Corporate Governance for Banking Organisation" published by the Bank for International Settlements in 2006, the Basel Committee on Banking Supervision notes the need to understand the banking governance. In pillar II, supervisory review, of the new Basel accord (Mc Donough ratio), the Basel Committee confirms the role of bank board of as an essential component of risk management. The major suggestion is that high-quality corporate governance increases monitoring efficiency of banks and he is the ultimately responsible for the operations and financial soundness of the bank. Also, Pathan and Skully (2010) show that the bank board of directors is even more important as a governance mechanism than its non-banks firm.

Previous studies had found that the link between mechanism of bank governance and bank performance is mixed and given the uniqueness of banking management. This study tries to explore the nature of relation between bank board, as an internal mechanism of banking governance, bank performance and bank risk-taking in Tunisian context.

This paper contribute to the existing literature by determining the characteristics relating to boards of banks sample, such as board size, independent directors, CEO ownership, and examine how they affect bank performance and bank risk taking in Tunisian commercial banks after banking reforms in 2001 and 2005. The remainder of the paper is organized as follows: Section 2 presents a brief review of earlier literature on board governance by discussion the role of the board on performance and bank risk-taking behaviour. Section 3 describes the data, retained variables, econometric approaches and major empirical results. Section 4 concludes the paper.

\section{Background and related literature}

Much of the empirical findings on corporate governance, performance and risk taking in non-financial institutions are also applicable to banks and they are mixed. According to Cheng (2008), the relation between characteristics of corporate boards (independence, size, CEO duality...) and firm performance continues to be a fundamental issue in the corporate governance literature.

\subsection{The impact of Board composition on firm performance and risk taking}

Complying with the teaching of the agency theory, the independent administrator's presence in the composition of board of directors seeks to align managerial decisions to the creation of the shareholder value. This theory adds that outside directors perform better than those internal for conflict resolution and mitigation of agency costs and moral hazard problems. A scan of the economic and financial literature enabled us to conclude that the link between independence board directors and performance leads to contradictory conclusions. Thus, unanimity about this relationship is not proven.

The first wave of research suggests that independence of the Board directors is accountable to high performance for the company. According to Fama (1980) and Fama and Jensen (1983), outside independent directors, contribute positively to effective control of managers in consideration of their incitement to exercise control. Board director's incitement to act in the interest of the company generally derives from the reputation that they would have on the market in terms of corporate control. Fama (1980) argues that outside director's act in the interest of the company in order to get new mandates. Liang and Li (1999) agree on a panel of 228 Chinese companies that the presence of outside directors helps to reduce agency costs through harmonization of interest between shareholders and managers. Therefore it contributes to hatching performance measured by Tobin's $Q$ and accounting measures. These authors also conclude that the presence of outsiders generate higher returns on investments undertaken by the firm.

Lefort and Urzúa (2008), using a sample of 160 Chilean companies, further support this hypothesis and confirm that the increased number of independent directors on the board promotes firm's performance. Dahya et al. (2008) 
adhere to this view and approve that a very independent board vis-a-vis managers ensures effective control and increases the market value of the firm, by undertaking a study on a sample of 799 firms. Leading an application on a sample of 78 firms over the period 1990-1995, Kor and Misangyi (2008) approve that the outsiders have good skills and they can act positively on company performance. Lunck et al. (2008) admit that the outsiders are less informed than insiders, but they are able to exercise more effective control on the board of directors and promote performance. They add that the outsiders are best placed to control the board of directors because they transpose their skill and experience to the firm. In addition, independent directors can counter the bad decisions of the CEO. Recently, Lin et al. (2009) reinforce the notion that board of directors is a mechanism which guarantees the company performance by protecting minority and majority shareholders.

Using a panel of 461 Chinese enterprises on the period 1999-2002, Lin et al. (2009) conclude that the independence of board of directors is closely related to an increase of around $10 \%$ efficiency of firms since it leads surely to good practice in corporate governance. Chen et al. (2009) confirm these findings by conducting a study of 101 Australian firms. An independent Board may exercise effective control over managers and hence, it promotes corporate performance, a conclusion also shared by Lau et al. (2009). Others like Schiehll and Bellavance (2009) agree that more independent directors enhance value creation within the firm. This idea has already been supported by Sarker and Sarker (2009). By conducting a survey of 500 companies listed on the Bombay Stock Exchange in India, they conclude that independent board of directors' members promotes value creation as independent administrators have to watch better governance than the internal ones.

Contrary to suggestions of the agency theory, a second wave of academic research about this relationship leads to the fact that the independence of board of directors negatively affects the performance of companies. The theory of stewardship questions the independence of the board of directors and applies that the managers are reliable and can act in interest of the firm. Other works following the example of Fosberg (1989) highlight that the companies the seats of the board of directors of which are occupied by a proportion of the external and independent administrators result in bad results. They add that the return on stockholders' equity and resulting collections sales undergo considerable declines. Yermack (1996) and Adams and Mehran (2003) reach the same conclusion. The proportion of the external and independent directors does not improve the performance of the company. Consequently, the firms which hold a reduced number of the independent directors in their boards will realize undoubtedly better performances. Sarkar and Sarkar (2009) confirm this conclusion in the Indian context. Kaymak and Bektas (2008) on the basis of a study carried out on 27 banks in Turkey over the period 2001-2004, conclude that is the insiders which drive to the increase of the returns on assets (ROA) and not the outsiders.

At the same time as these works which try to identify the junction between the independence of the board of directors and the realization of the firm performances, there is a hybrid current in the financial literature between advanced theories of agency and stewardship. This current reaches the conclusion that the independence of the board of directors has no effect on company performance. The examination of Morck and al. (1988) robust works allowed us to conclude that the independence of board members does not necessarily improve performance. Hermalin and Weisbach (1991) and Bhagat and Black (2002) help such observation going further in their analysis. Performance and value creation for the company are based on other variables besides the independence of the Board. Hermalin and Weisbach (1991) argue for this neutral organization based on the incompetence of outside directors to decipher the complex operations and policies of the firm. They add that this class of directors is faced with enormous difficulties in supervising managers.

\subsection{The impact of Board size on firm performance and risk taking}

Cheng et al. (2008) consider the importance of board of directors' size in the corporate governance process is well recognized. An examination of the relationship between board's size and performance highlights contradictory results. This leads to a lack of consensus regarding this relationship. Yermack (1996) was the first to study the correlation between board's size and firm performance measured by Tobin's Q on a sample of 452 U.S. firms over the period going from 1984 to 1991 . So, he concludes that there is a statistically significant relationship between board of directors' size and performance. In this regard, the board of directors' size was proved to be negatively associated with companies' profitability. To complete the analysis of this correlation, Cheng et al. (2008) focused on 350 firms of Yermack (1996)'s sample over the same period and have reached the conclusion that the board directors' size is negatively related to performance measured by Tobin's Q and return of assets ratio (ROA). Bennedsen et al. (2008) approve this correlation on a panel of 700 companies in Denmark. However, Kiel and Nicholson (2003) found a positive relationship between board directors' size and performance in Australia.

Lipton and Lorsch (1992) and Jensen (1993) argue that large boards are generally less efficient than smaller ones. A small board of directors can effectively controls, protects the interests of all stakeholders, aligns the 
decisions between directors and managers of the firm and reduces agency costs between board members. These authors add that it is difficult for large boards to organize meetings, to reach consensus and to quickly react because of the costs of communication and coordination. Cheng et al. (2008) argue that the problems are more pronounced with larger boards. Cheng et al. (2008) confirm this conclusion by demonstrating that the reduction of one board member causes a 4.18\% increase in Tobin's Q. By driving an application, on a panel of 1252 companies over the period 1996-2004, Cheng et al. (2008) concluded that large boards, approximated by the number of board of directors members, is negatively correlated with the annual return on assets, Tobin's $Q$, the spending on research and development, the frequency of acquisition and restructuring activities. The author justifies this negative junction by the difficulties of communication, coordination and arrangement between the members of the large-sized board.

Andres and Vallelado (2008) confirm these ideas by conducting a study on 69 boards of the largest banks in Canada, USA, Spain, Britain, France and Italy over the period 1995-2005. They conclude that a small board of directors is more efficient. Lau and al. (2009) stipulate that the small board of directors' size could be more effective when disciplinary measures to the failing managers are imposed. The authors quote as an example the decision to dismiss a Chief Executive Officer ( CEO) requiring the unanimity, which can be, often, easy to have in this kind of board of directors. By investigating the banking sector, Adam and Mehram (2003), mark down these works and underline that the banks who have a large board of directors will realize better performances associated with high risk levels. They also showed that when a board size is small, its members can easily be manipulated and influenced by managers. Indeed, the size of the board of directors may also have an impact on managers' risk taking behaviour. Blanchard and Dionne (2004) suggested that the higher the number of directors is, the higher the use of sophisticated instruments to hedge against the risk increases, which justifies managers excessive risk taking. We expect that a large board could help better assess the risk of investment projects, thanks to the diversified structure and the best expertise that characterize a large board of directors, reducing the banks risk. Thus, we expect the size of the board of directors to have a negative impact on the insolvency and credit's risks: the more it increases, the less the insolvency and credit's risks are.

\section{The Empirical study}

\subsection{Presentation of models and the sample}

To study the empirical association between board structure and performance and between board structure and banks risk taking, we will refer to the study of Pathan (2009) conducted in American banks. The models to be tested are the followings:

Equation 1:

$$
\begin{aligned}
& \text { Performance }_{i, t}=a+\beta_{1} \operatorname{Ln}(\mathrm{BS})_{i, t}+\beta_{2}(\text { INDIR })_{i, t}+\beta_{3}(\mathrm{CEOWN})_{i, t}+\beta_{4} \operatorname{Ln}(\mathrm{TA})_{i, t}+\beta_{5}(\mathrm{CV})_{i, t} \\
& +\beta_{6}(\text { MERGER })_{i, t}+\sum_{1997}^{2006} \xi(\text { Year })_{i}+\varepsilon_{i, t}
\end{aligned}
$$

Equation 2:

$$
\begin{aligned}
& \operatorname{Ln}(\text { Risk })_{i, t}=a+\beta_{1} \operatorname{Ln}(B S)_{i, t}+\beta_{2}(\text { INDIR })_{i, t}+\beta_{3}(C E O W N)_{i, t}+\beta_{4} \operatorname{Ln}(T A)_{i, t}+\beta_{5}(C V)_{i, t} \\
& +\beta_{6}(\text { MERGER })_{i, t}+\sum_{1997}^{2006} \xi(\text { Year })_{i}+\varepsilon_{i, t}
\end{aligned}
$$

- Where subscripts i denotes individual banks $(i=1,2, \ldots, 11), t$ time period $(t=1997,1998, \ldots, 2006)$ and $\mathrm{Ln}$ is the natural logarithmic. $\beta$ are the parameters to be estimated. $\varepsilon$ is the error term.

- Performance: Because there exists no single, unique measure of bank performance, we employ two alternatives. These include ROA (return on assets) and ROE (return on equity).

- Risk: Several different measures of bank risk-taking have been used in empirical studies: credit risk and overall bank risk. In this study, according to Laeven and Levine (2009), we measure bank risk taking using the Z-score of each bank, which equals the return on assets (ROA) plus capital asset ratio divided by the standard deviation of asset returns. A higher Z-score indicates that the bank is more stable. Because the $\mathrm{z}$-score is highly skewed, we use the natural logarithm of the z-score, which is normally distributed.

- Board size (BS): The number of directors in the bank board. 
- Independent directors (INDIR): The percentage of total directors who are independent. According to Pathan (2009), an independent director has only business relationship with the bank is his or her directorship, i.e. an independent director is not an existing or former employee of the banks or its immediate family members and does not have any significant business ties with the bank.

- CEO ownership (CEOWN): The percentage of the banks CEO's shareholdings.

- Bank size (TA): Total assets as at the end of each fiscal year.

- Charter value (CV): Keeley's Q (Keeley, 1990) which is calculated as the sum of the market value of equity plus the book value of liabilities divided by the book value of total assets.

- Previous M\&A (MERGER): A dummy for any previous period MandA, i.e. a dummy variable which equals one for banks that made an acquisition in a year, otherwise zero.

- Year dummies (YEAR): Eleven individual dummy variables which equals either one or zero for each year from 1997 to 2006 with 1997 being the excluded year

The sample examined in this paper consists of the largest banks in Tunisia over the period 1997-2006. The data is sourced from Tunis Stock Exchange. Table 1 provides descriptive statistics for all the data used in this study.

\subsection{Econometric tests and major results}

Like Pathan (2009), the first estimate Eq. (1) and Eq.(2) using generalized least square (GLS) random effect (RE) technique. For robustness tests, we estimate the same regressions using Generalized Method of Moments (GMM). Following the assumption of Blundell and Bond (1998), suggesting that first differences of instrumental variables are uncorrelated with the fixed effects, we use GMM system method. This last method retains a system of two equations-the original equation as well as the transformed one-. The Arellano and Bond test for autocorrelation has a null hypothesis of no autocorrelation and is applied to the differenced residuals. The test for AR (2) in first differences is more important, because it will detect autocorrelation in terms of levels. The validity of the instrumental variables is tested using Hansen test of over-identifying restrictions and over a test of the absence of serial correlation of the residuals. As our data contain a small number of banks, we use the method one-step GMM-in-System estimator. All models include time dummies and they are estimated by GLS RE and GMM system.

\subsubsection{Board characteristics and bank performance}

Using the generalized least square random effect, the regression Eq. (1) is well-fitted with an overall R squared of $31.28 \%$ and $7.83 \%$ for ROA and ROE respectively with statistically significant Wald Chi-square $\chi^{2}$ statistics. With regards to board characteristics, the coefficient on BS is negative (-0.001 and -0.008) across all two measures of performance and respectively statistically significant at the level of $10 \%$ for ROA and $1 \%$ for ROE. This result suggests that, a small bank board is associated with more performance and that the addition of new directors in Tunisian banks' board affects negatively the performance of bank firms. This outcome is consistent with Yermack (1996), Cheng et al. (2008) and Bennedsen et al. (2008) and inconsistent with corporate firm evidence by Lipton and Lorsch (1992) and Jenson (1993). The coefficient on TA is also negative $\left(-4.92^{\mathrm{e}-12}\right)$ and statistically significant at the level of $1 \%$ for ROA and $\left(-4.92^{\mathrm{e}-11}\right)$ and statistically significant at the level of $10 \%$ for ROE. The presence of independent members on board not enhances bank performance; the coefficient on INDIR is negative (-0.005 for ROA and -0.034 for ROE) and not statistically significant. This result corroborate corporate firm works of Sarkar and Sarkar (2009) and Bhagat and Bolton (2008) and with bank evidence by Adams and Mehran (2003) but not consistent with Hermalin and Weisbach (1991) and Bhagat and Black (2002). Moreover, the coefficient on CEOWN is negative ( -0.003 for ROA and -0.005 for ROE) and not statistically significant. This result illustrates that lower CEO ownership is associated with lower performance in Tunisian banks. Similar to expectation, the coefficient on $\mathrm{CV}$ is negative ( -0.008 for ROA and -0.168 for ROE) and respectively not statistically significant. This result indicates that banks with high charter value are associated with lower ROA and ROE.

For robustness checks, we perform the analysis by using the GMM system technique of Blundell and Bond (1998). The Hansen and serial-correlation tests do not reject the null hypothesis of correct specification (P-value of Hansen test and AR (2) test of Arellano and Bond are larger than 5\% for ROA (respectively 0.854 and 0.283 ) and ROE (respectively 0.897 and 0.755 )), lending support to our estimation results. The reported coefficient estimates are similar to the results of generalized least square random effect technique.

\subsubsection{Board characteristics and bank risk taking behaviour}

Using the generalized least square random effect, the regression Eq. (2) is well-fitted with an overall R squared of $66.95 \%$ for $1 / Z$-score with statistically significant Wald Chi-square $\chi^{2}$ statistics. The coefficient associated to BS is 
negative (-0.005) across the measure of bank risk and statistically significant at the level of $10 \%$. This illustrates that, a small bank board is associated with more bank risk-taking. This result corroborates the findings of Pathan (2009) for US banks. Turning our attention to the variable TA, we find that it is negative $\left(-1.61^{\mathrm{e}-13}\right)$ and not significant. This implies that in general, the small size banks institutions assume lower risks. The coefficients on $\mathrm{CV}$ and CEOWN are still positive (respectively 0.046 and 0.002 ) and statistically significant for the former at the $1 \%$ level. This result illustrates that banks with high charter value (CV) are associated with more bank risk. Our findings about the statistically significant positive coefficient on CEOWN across insolvency risk point to clear evidence that as the percentage of CEOs shareholdings increase their risk preference increase. The results of CV and CEOWN, however, are consistent with findings of Pathan (2009) for 212 large US banks over 1997-2004. Contrary to expectation, the coefficient on INDIR is negative $(-0.001)$ and not statistically significant for insolvency risk (1/Ln (Z-score)). This finding is robust with works of Fama (1980), Fama and Jenson (1983), Kor and Misangyi (2008), Dahya et al. (2008), Lunck et al. (2008), Lau et al. (2009) and Schiehll and Bellavance (2009) for non-bank firms. For robustness tests, the GMM system technique has been used to explore findings of GLS RE. The Hansen and serial-correlation tests do not reject the null hypothesis of correct specification (P-value of Hansen test and AR (2) test of Arellano and Bond are larger than 5\%, with respectively 0.510 and 0.970 ), lending support to our estimation results. The reported coefficient estimates are similar to the results issued from generalized least square random effect technique except for INDIR. Consistent with expectation, the coefficient on INDIR is positive (0.171) and not statistically significant for insolvency risk. Pathan (2009), using two-step system GMM, find a negative and not statistically significant coefficient between INDIR and (1/Ln(Z-score)).

\section{Conclusion}

The last decade has seen several important advances in the empirical literature of corporate governance. The specific nature and the key role of banks in the economy justify the necessity of bank governance. Bank board characteristics play a central role in high-quality bank governance. This paper investigates whether board characteristics relate to bank performance and bank risk taking behavior in Tunisia. We use two econometric approaches: the generalized least square random effect and GMM system (one-step GMM-in-System estimator). We find that a small bank board is associated with more performance and with more bank risk-taking, a lower CEO ownership is associated with lower performance in Tunisian banks, banks with high charter value are associated with lower ROA and ROE and more bank risk and the small size banks institutions appear to assume lower risks. The results in this paper imply that bank board characteristics and structure play a crucial role in bank performance and bank risk taking. The board is a key mechanism to control and monitor managers' behaviour.

To enhance academic understanding of this subject, this research can be extended by introducing other alternatives of bank performance (Tobin's Q, annual market return of a bank shareholder) and bank risk-taking (systematic risk, assets return risk, credit risk and overall bank risk). Given the vital role and the importance of banking governance in the economy, the policy implications of our findings are straightforward: to maintain an efficient banking system, all countries must strengthen banking governance. To promote bank performance and supervise bank board, Tunisia is working to upgrade banking governance because board of directors works well for banks subject to regulatory constraints. A well-functioning banking sector can positively contribute to promote performance and control for excessive risk taking in both developing and developed countries. In this light, good practices of banking governance have to lead to a stronger economic growth.

\section{Acknowledgements}

Dr. Rachdi and Dr. Ghazouani aknowledge the editor Suri Lee and the external reviewer of the International Journal of Business and Management for useful comments.

\section{References}

Adams, R.B., \& Mehran H. (2003). Board structure and banking firm performance and the bank holding company organizational form. Working Papers of Federal Reserve Bank of Chicago, 408-422.

Andres, P., \& Vallelado E. (2008). Corporate governance in banking: The role of the board of directors. Journal of Banking and Finance, 32, 2570-2580.

Basel Committee on Banking Supervision. (2006). Enhancing corporate governance for banking organizations, BIS.

Bennedsen, M., Kongsted, H.C., \& Nielsen K.M. (2008). The causal effect of board size in the performance of small and medium-sized firms. Journal of Banking and Finance, 32, 1098-1109. 
Bhagat, S., \& Black B.S. (2002). Board independence and long term firm performance. Journal of Corporation Law, 27, 231-273.

Bhagat, S., \& Bolton B. (2008). Corporate governance and firm performance. Journal of Corporate Finance, 14, 257-273.

Blanchard, D., \& Dionne G. (2004). Gestion des risques et gouvernance d'entreprise. Assurances et gestion des risques, 71, 397-406.

Brickley, J.A., Coles, J.L., \& Jarrell G. (1997). Leadership structure: Separating the CEO and chairman of the board. Journal of Corporate Finance, 3, 189-220.

Cannella, A., \& Lubtakin M. (1993). Succession as a sociopolitical process: Internal impediments to outsider succession. Academy of Management Journal, 36, 763-793.

Caprio, G., Laeven, L., \& Levine R. (2007). Governance and bank valuation. Journal of Financial Intermediation, $16,584-617$.

Chen, R., Dyball, M.C., \& Wright S. (2009). The link between board composition and corporate diversification in Australian corporations. Corporate Governance: An International Review, 17, 208-223.

Cheng, S. (2008). Board size and the variability of corporate performance. Journal of Financial Economics, 87, 157-176.

Cheng, S., Evans, J.H., \& Nagarajan N.J. (2008). Board size and firm performance: the moderating effects of the market for corporate control. Review of Quantitative Financial Accounting, 31, 121-145.

Dahya, J., Dimitrov, O., \& McConnell J.J. (2008). Dominant shareholders, corporate boards, and corporate value: A cross-country analysis. Journal of Financial Economics, 87, 73-100.

Elsayed, K. (2007). Does CEO duality really affect corporate performance? Corporate Governance: An International Review, 15, 1203-1214.

Fama, E.F. (1980). Agency problems and the theory of the firm. Journal of Political Economy, 88, 288-307.

Fama, E.F., \& Jensen M.C. (1983). Separation of ownership and control. Journal of Law and Economics, 26, 301-325.

Fosberg, R. (1989). Outside directors and managerial monitoring. Akron Business and Economic Review, 20, 24-32.

Hermalin, B.E., \& Weisbach M.S. (1991). The effects of board composition and direct incentives on firm performance. Financial Management, 20, 101-112

Jensen, M.C. (1993). The modern industrial revolution, exit, and the failure of internal control systems, Journal of Finance, 48, 831-880.

Kaymak, T., \& Bektas E. (2008). East meets west? Board characteristics in an emerging market: Evidence from Turkish Banks. Corporate Governance, 16, 550-561.

Kiel, G.C., \& Nicholson G.J. (2003). Board composition and corporate performance: How the Australian experience informs contrasting theories of corporate governance. Corporate Governance, 11, 189-205.

Kor, Y.Y., \& Misangyi V.F. (2008). Outside directors industry-specific experience and firm's liability of newness. Strategic Management Journal, 29, 1345-1355.

Laeven, L., \& Levine R. (2009). Bank governance, regulation, and risk taking. Journal of Financial Economics, 93, 259-275.

Lau, J., Sinnadurai, P., \& Wright S. (2009). Corporate governance and chief executive officer dismissal following poor performance: Australian evidence. Accounting and Finance, 49, 161-182.

Lefort, F., \& Urzúa F. (2008). Board independence, firm performance and ownership concentration: Evidence from Chile. Journal of Business Research, 61, 615-622.

Liang, N., \& Li J. (1999). Board structure and firm performance: New evidence from China's private firms. China Center for Economic Research, 1-32.

Lin, C., Ma, Y., \& Su D. (2009). Corporate governance and firm efficiency: Evidence from China's publicly listed firms. Managerial and Decision Economics, 30, 193-209. 
Linck, J.S, Netter, J.M., \& Yang T. (2008). The determinants of board structure. Journal of Financial Economics, 87, 308-328.

Lipton, M., \& Lorsch J. (1992). A modest proposal for improved corporate governance. Business Lawyer, 48, 59-77.

Mamoghli, C., \& Dhouibi R. (2009). Bank corporate governance and insolvency risk evidence from an emerging market. Working paper, 1-32.

Morck, R., Shleifer, A., \& Vishny R (1988). Managerial ownership and market valuation. Journal of Financial Economics, 20, 293-315.

Morey, M., Gottesman, A., Baker, E., \& Godridge B. (2009). Does better corporate governance result in higher valuations in emerging markets? Another examination using a new data set. Journal of Banking and Finance, 33, 254-262.

Pathan S., Skully M., \& Wickramanayake J. (2008). Reforms in Thai banking governance: The aftermath of the Asian financial crisis. International Review of Financial Analysis, 17, 345-362.

Pathan, S. (2009). Strong boards, CEO power and bank risk-taking. Journal of Banking and Finance, 33, 1340-1350.

Pathan, S., \& Skully M. (2010). Endogenously structured boards of directors in banks. Journal of Banking and Finance, 34, 1590-1606.

Pi, L., \& Timme S.G. (1993). Corporate control and bank efficiency. Journal of Banking and Finance, 17, 515-530.

Rachdi, H., \& Elgaied M. (2009). L'impact de l'indépendance et de la dualité du conseil d'administration sur la performance des entreprises: Application au contexte Américain. Revue Libanaise de Gestion et d'Economie, 3, $1-24$.

Rechner, P., \& Dalton D.R. (1991). CEO duality and organizational performance. Strategic Management Journal, 12, 155-160.

Roodman, D. (2006). How to do xtabond2: An Introduction to "Difference" and "System" GMM in Stata. Center for Global Development Working Paper Series.

Sarkar, J., \& Sarkar S. (2009). Multiple board appointments and firm performance in emerging economies: Evidence from India. Pacific-Basin Finance Journal, 17, 271-293.

Schiehll, E., \& Bellavance F. (2009). Boards of directors, CEO ownership, and the use of non-financial performance measures in the CEO bonus plan. Corporate Governance: An International Review, 17, pp 90-106.

Smith, A. (1776). An inquiry into the nature and causes of the wealth of nations. Edition Flammarion, Paris.

Sridharan, U.V., \& Marsinko A. (1997). CEO duality in the paper and forest products industry. Journal of Financial and Strategic Decisions, 10, 59-65.

Tuggle, C.R., Reutzel, C.R., \& Bierman L. (2008). CEO duality \& board attention to monitoring and control. Academy of Management Proceedings, 1-6.

Table 1. Descriptive statistics

\begin{tabular}{l|ccccc}
\hline VARIABLES & Obs & Mean & $\begin{array}{c}\text { Standard } \\
\text { Deviation }\end{array}$ & Minimum & Maximum \\
\hline Return on equity (ROE) & 110 & 0.068 & 0.183 & -1.765 & 0.207 \\
Return on assets (ROA) & 110 & 0.012 & 0.013 & -0.08 & 0.066 \\
Z-score & 110 & 0.00020 & 0.0024 & -0.000034 & 0.0010 \\
Board size (BS) & 110 & 11.418 & 1.357 & 9 & 15 \\
Independent directors (INDIR) & 110 & 0.060 & 0.127 & 0 & 0.444 \\
CEO ownership (CEOWN) & 110 & 0.072 & 0.231 & 0 & 0.80 \\
Bank size (TA) & 110 & $1.93 \mathrm{e}+09$ & $1.12 \mathrm{e}+09$ & $1.75 \mathrm{e}+08$ & $4.71 \mathrm{e}+09$ \\
Charter value (CV) & 110 & 0.838 & 0.183 & 0.08 & 0.954 \\
M\&A (MERGER) & 110 & 0.272 & 0.447 & 0 & 1 \\
\hline
\end{tabular}


Table 2. Board characteristics and alternative measures of bank performance: GLS RE and GMM system approaches

\begin{tabular}{|c|c|c|c|c|c|c|c|}
\hline \multicolumn{2}{|c|}{$\begin{array}{c}\text { GLS RE } \\
\text { Dependant variable: } \\
\text { ROA }\end{array}$} & \multicolumn{2}{|c|}{$\begin{array}{c}\text { GLS RE } \\
\text { Dependant variable: } \\
\text { ROE }\end{array}$} & \multicolumn{2}{|c|}{$\begin{array}{c}\text { GMM system } \\
\text { Dependant variable: } \\
\text { ROA }\end{array}$} & \multicolumn{2}{|c|}{$\begin{array}{c}\text { GMM system } \\
\text { Dependant variable: } \\
\text { ROE }\end{array}$} \\
\hline Variables & Coefficient & Variables & Coefficient & Variables & Coefficient & Variables & Coefficient \\
\hline BS & $\begin{array}{c}-0.001^{*} \\
(1.77)\end{array}$ & BS & $\begin{array}{c}-0.008^{* * *} \\
(-2.59)\end{array}$ & ROA (-1) & $\begin{array}{l}0.222 \\
(1.15)\end{array}$ & ROE (-1) & $\begin{array}{l}0.497 \\
(0.45)\end{array}$ \\
\hline TA & $\begin{array}{c}-4.92^{\mathrm{e}-12^{* * *}} \\
(-3.44)\end{array}$ & TA & $\begin{array}{c}-4.92^{\mathrm{e}-11^{*}} \\
(-1.81)\end{array}$ & $\mathrm{BS}$ & $\begin{array}{l}-0.004 \\
(-0.39)\end{array}$ & $\mathrm{BS}$ & $\begin{array}{l}-0.151 \\
(-0.66)\end{array}$ \\
\hline $\mathrm{CV}$ & $\begin{array}{l}-0.009 \\
(-1.13)\end{array}$ & $\mathrm{CV}$ & $\begin{array}{l}-0.168 \\
(1.35)\end{array}$ & TA & $\begin{array}{c}-1.02^{\mathrm{e}-11^{1 * *}} \\
(-1.95)\end{array}$ & TA & $\begin{array}{c}-2.24^{\mathrm{e}-11^{*}} \\
(-1.68)\end{array}$ \\
\hline INDIR & $\begin{array}{l}-0.005 \\
(-0.47)\end{array}$ & INDIR & $\begin{array}{l}-0.034 \\
(-0.18)\end{array}$ & $\mathrm{CV}$ & $\begin{array}{l}-0.059 \\
(-1.29)\end{array}$ & $\mathrm{CV}$ & $\begin{array}{l}-0.185 \\
(-0.20)\end{array}$ \\
\hline MERGER & $\begin{array}{c}-0.009^{* * *} \\
(-2.46)\end{array}$ & MERGER & $\begin{array}{c}-0.124 \\
(-2.04)^{* *}\end{array}$ & INDIR & $\begin{array}{l}-0.047 \\
(-0.13)\end{array}$ & INDIR & $\begin{array}{l}-2.554 \\
(-0.42)\end{array}$ \\
\hline CEOWN & $\begin{array}{l}-0.003 \\
(-0.49)\end{array}$ & CEOWN & $\begin{array}{l}-0.005 \\
(-0.01)\end{array}$ & MERGER & $\begin{array}{l}-0.105^{*} \\
(-1.70)\end{array}$ & MERGER & $\begin{array}{c}-1.969^{* * *} \\
(-2.40)\end{array}$ \\
\hline Constant & $\begin{array}{c}0.051^{* * *} \\
(4.21)\end{array}$ & Constant & $\begin{array}{l}0.144 \\
(0.75)\end{array}$ & & $\begin{array}{l}-0.051 \\
(-0.06)\end{array}$ & CEOWN & $\begin{array}{l}-1.006 \\
(-0.16)\end{array}$ \\
\hline Year & Included & Year & Included & Constant & $\begin{array}{l}0.163 \\
(0.81)\end{array}$ & Constant & $\begin{array}{l}3.201 \\
(1.31)\end{array}$ \\
\hline & & & & Year & Included & Year & Included \\
\hline $\begin{array}{l}\text { Number of } \\
\text { Banks }\end{array}$ & 11 & $\begin{array}{l}\text { Number of } \\
\text { Banks }\end{array}$ & 11 & $\begin{array}{c}\text { Number of } \\
\text { Banks }\end{array}$ & 11 & $\begin{array}{c}\text { Number of } \\
\text { Banks }\end{array}$ & 11 \\
\hline $\begin{array}{c}\text { P-value of } \\
\text { Wald } \chi^{2} \\
\text { statistics }\end{array}$ & 0.000 & $\begin{array}{c}\text { P-value of } \\
\text { Wald } \chi^{2} \\
\text { statistics }\end{array}$ & 0.000 & $\begin{array}{c}\text { P-value of } \\
\text { Wald } \chi^{2} \\
\text { statistics }\end{array}$ & 0.000 & $\begin{array}{c}\text { P-value of } \\
\text { Wald } \chi^{2} \\
\text { statistics }\end{array}$ & 0.000 \\
\hline Within $\mathrm{R}^{2}$ & 0.0810 & $\mathrm{R}^{2}$ within & 0.0391 & $\begin{array}{c}\text { Arellano } \\
\text { and Bond } \\
\text { test for AR } \\
\text { (2) }\end{array}$ & -0.18 & $\begin{array}{c}\text { Arellano } \\
\text { and Bond } \\
\text { test for } \\
\text { AR (2) }\end{array}$ & -0.13 \\
\hline Between $\mathrm{R}^{2}$ & 0.8253 & $\mathrm{R}^{2}$ between & 0.3544 & $\begin{array}{c}\text { P-value of } \\
\text { AR (2) }\end{array}$ & 0.854 & $\begin{array}{c}\text { P-value of } \\
\text { AR (2) }\end{array}$ & 0.897 \\
\hline Overall $\mathrm{R}^{2}$ & 0.3128 & Overall $\mathrm{R}^{2}$ & 0.0783 & $\begin{array}{c}\text { Hansen } \\
\text { J-statistics }\end{array}$ & 6.25 & $\begin{array}{c}\text { Hansen } \\
\text { J-statistics }\end{array}$ & 2.64 \\
\hline Rho & 0.6622 & Rho & 0.0858 & $\begin{array}{c}\text { P-value of } \\
\text { Hansen test }\end{array}$ & 0.283 & $\begin{array}{l}\text { P-value of } \\
\text { Hansen test }\end{array}$ & 0.755 \\
\hline
\end{tabular}

\section{Note:}

Estimation methods are generalized least square random effect and one-step GMM-in-System estimator (Xtabond2).

The reported t-statistics with GLS RE estimates are robust to random fixed-effect and also for heteroskedasticiy.

Year is a time dummy.

All models include time dummies and they are estimated by GLS RE and GMM system and are significant in all cases.

AR (2): test of null of zero second-order serial correlation, distributed $N(0,1)$ under null.

The numbers in parentheses are t-statistics.

$*, * *$, and $* * *$ indicate statistical significance at the $1 \%, 5 \%$, and $10 \%$ level

Banks are Amen Bank, Arab Tunisian Bank, Banque de l'Habitat, Banque Internationale Arabe de Tunisie, Banque Nationale Agricole, Attijari Bank, Banque de Tunisie, Société Tunisienne de Banque, Banque de Tunisie et des Emirats, Union Internationale de Banques and Union Bancaire pour le Commerce et l'Industrie. 
Table 3. Board structure and bank risk taking: GLS RE and GMM system approaches

\begin{tabular}{|c|c|c|c|}
\hline \multicolumn{2}{|c|}{$\begin{array}{c}\text { GLS RE } \\
\text { Dependant variable: (1/Ln (Z-score)) }\end{array}$} & \multicolumn{2}{|c|}{$\begin{array}{c}\text { GMM system } \\
\text { Dependant variable: (1/Ln (Z-score)) }\end{array}$} \\
\hline Variables & Coefficient & Variables & Coefficient \\
\hline $\mathrm{BS}$ & $\begin{array}{l}-0.005^{* *} \\
(-1.95)\end{array}$ & $(1 / \operatorname{Ln}(\mathrm{Z}$-score $))(-1)$ & $\begin{array}{l}-0.272 \\
(-0.82)\end{array}$ \\
\hline TA & $\begin{array}{l}-1.61^{e-13} \\
(-0.18)\end{array}$ & $\mathrm{BS}$ & $\begin{array}{l}-0.010^{* *} \\
(-1.95)\end{array}$ \\
\hline $\mathrm{CV}$ & $\begin{array}{l}0.046^{* * *} \\
(3.74)\end{array}$ & TA & $\begin{array}{l}-6.41^{\mathrm{e}-13} \\
(-0.17)\end{array}$ \\
\hline INDIR & $\begin{array}{l}-0.001 \\
(-0.14)\end{array}$ & $\mathrm{CV}$ & $\begin{array}{l}0.049 \\
(2.01)\end{array}$ \\
\hline MERGER & $\begin{array}{l}0.001 \\
(0.55)\end{array}$ & INDIR & $\begin{array}{l}0.171 \\
(0.77)\end{array}$ \\
\hline CEOWN & $\begin{array}{c}0.002^{* * *} \\
(2.55)\end{array}$ & MERGER & $\begin{array}{l}0.053 \\
(0.20)\end{array}$ \\
\hline Constant & $\begin{array}{l}-0.146^{* * *} \\
(-2.19)\end{array}$ & CEOWN & $\begin{array}{l}0.673^{*} \\
(1.68)\end{array}$ \\
\hline & & Constant & $\begin{array}{l}-0.135^{* * *} \\
(-2.53)\end{array}$ \\
\hline Year & Included & Year & Included \\
\hline Number of Banks & 11 & Number of Banks & 11 \\
\hline $\begin{array}{l}\text { P-value of Wald } \chi^{2} \\
\text { statistics }\end{array}$ & 0.000 & $\begin{array}{l}\text { P-value of Wald } \chi^{2} \\
\text { statistics }\end{array}$ & 0.001 \\
\hline Within $\mathrm{R}^{2}$ & 0.5414 & $\begin{array}{l}\text { Arellano and } \\
\text { Bond test for AR (2) }\end{array}$ & -0.66 \\
\hline Between $\mathrm{R}^{2}$ & 0.7948 & P-value of AR (2) & 0.510 \\
\hline Overall $\mathrm{R}^{2}$ & 0.6695 & Hansen J-statistics & 0.24 \\
\hline Rho & 0.2459 & $\begin{array}{l}\text { P-value of Hansen } \\
\text { J-statistics }\end{array}$ & 0.970 \\
\hline
\end{tabular}

Note:

Estimation methods are generalized least square random effect and one-step GMM-in-System estimator (Xtabond2).

$(1 / \mathrm{Ln}(\mathrm{Z}$-score $))$ is insolvency risk.

The reported t-statistics with GLS RE estimates are robust to random fixed-effect and also for heteroskedasticiy.

Year is a time dummy.

All models include time dummies and they are estimated by GLS RE and GMM system and are significant in all cases.

AR (2): test of null of zero second-order serial correlation, distributed $\mathrm{N}(0,1)$ under null.

The numbers in parentheses are t-statistics.

$*, * *$, and $* * *$ indicate statistical significance at the $1 \%, 5 \%$, and $10 \%$ level.

Banks are Amen Bank, Arab Tunisian Bank, Banque de l'Habitat, Banque Internationale Arabe de Tunisie, Banque Nationale Agricole, Attijari Bank, Banque de Tunisie, Société Tunisienne de Banque, Banque de Tunisie et des Emirats, Union Internationale de Banques and Union Bancaire pour le Commerce et l'Industrie. 